\title{
Clitoridectomy and Urethrostomy in a Pseudohermaphrodite Dog
}

\author{
Juliane Laís Roman', Ariele Aparecida Ferreira', Ana Paula Rossa', \\ Wisley lemanjá Malaquias dos Santos ${ }^{1}$, Renato Silva de Souza', Jorge Luiz Costa Castro², \\ Vinicius Gonzalez Peres Albernaz ${ }^{1} \&$ Peterson Triches Dornbusch ${ }^{1}$
}

\begin{abstract}
Background: Hermaphroditism is a rare congenital disease that causes ambiguous sexual features. True hermaphrodites have testicular and ovarian tissue, whereas pseudohermaphrodites have only one type of gonadal tissue and genitalia, but secondary characteristics of the opposite sex. Pseudohermaphrodites are classified as male or female according to their gonads. Treatment of pseudohermaphroditism consists of surgical removal of the gonads including reconstruction of abnormal genitalia, especially if the urethra is involved. Therefore, the objective of this report is to describe a case of a male pseudohermaphrodite in a dog treated with clitoridectomy with urethrostomy.

Case: A 7-month-old, mixed-breed dog was referred due to the presence of a flaccid structure similar to a small penis, containing an os clitoris, bulbourethral glands, and urethra protruding from the vulva. Physical examination, complete blood count and serum biochemistry were within normal ranges. Hormonal levels of estradiol, testosterone, and progesterone were $56.39 \mathrm{pg} / \mathrm{mL}, 127.9 \mathrm{ng} / \mathrm{mL}$, and $0.892 \mathrm{ng} / \mathrm{mL}$, respectively. The abdominal ultrasound and posteriorly the exploratory celiotomy found a normal size prostate and two round organs resembling testicles connected to a uterus-like tubular structure. The patient underwent surgical abdominal exploration that confirmed the ultrasonographic findings and led to gonadohysterectomy. Also, clitoridectomy and urethrostomy were performed to excise the protruded structure and maintain normal urethral patency. The histopathological examination of the clitoris and penis confirmed it was a male genital organ, however, the abdominal structures were compatible with the testicles, epididymis, uterus, and even a broad ligament. These organs are normally found in cases of male pseudohermaphroditism. The testicles were histologically composed of regular seminiferous tubules, single layer Sertoli cells but there were no spermatogenic cells. After ten months of follow-up, the patient was alive, without urination impairment or any other clinical signs.

Discussion: The animal presented the protrusion of the penile structure as the sole clinical sign. The reproductive system had a female origin, been possible its masculinization due to high testosterone concentration that induced the development of Wolff ducts, resulting in the formation of the epididymis, deferent ducts, and seminal vesicles. In these cases, it led to an enlarged clitoris. The patient described had hormonal levels compatible with a neutered male/female or a female in anestrus. The clinical signs become evident as the clitoris gets hypertrophied increasing the sensibility, resulting in constant licking of the mucosa, chronic inflammation, and mucopurulent discharge. This patient was diagnosed with male pseudohermaphroditism as it had cryptorchid male gonads along with the uterus and external genitalia of a female dog but containing traces of male genitals such as the os clitoris. Surgery is indicated when there are clinical signs or when the clitoris had an os clitoris or urethra due to an intersex abnormality. The surgical resection of the external male genitalia associated with the excision of the internal reproductive tract treated while preserving the urethra in this animal. Clitorectomy is a simple technique and creates a normal female anatomy ending the clinical signs of the exposed clitoris and improving the quality of life.
\end{abstract}

Keywords: congenital anomaly, dogs, hermaphroditism. 


\section{INTRODUCTION}

The hermaphroditism or intersex is a condition in which ambiguous sexual characteristics result from congenital abnormalities of the genital system [5]. It is considered rare in domestic animals [17]. However, the occurrence may be higher since few published studies are addressing this disease [8].

Patients with true hermaphrodites have testicular and ovarian tissues, whereas those with false hermaphrodites have only one type of gonad, but a genitalia and secondary phenotype of the opposite sex. These animals are classified as male or female according to their gonads [9]. Male pseudohermaphrodite dogs are chromosomally $78 \mathrm{XY}$, have external male genitalia, and an internal one composed of fallopian tubes, uterus, and cranial portion of the vagina [15].

The history, clinical exam, hormonal levels, and ultrasound are triage exams for suspected hermaphroditism. Karyotyping is necessary to determine the formation of the sex chromosomes; histology of the gonad, internal, and external genitalia are complements to obtain a definitive diagnosis [14]. The abnormal development of the clitoris may be caused by hypertrophy, and/or by an internal bone structure called os clitoris [10].

Gonadectomy should be performed to avoid relapse, neoformation, and infection or inflammatory process. If the urethra is located inside the clitoral formation, the surgical intervention must include the reconstruction of the malformed penis [13]. This report aims to describe the clinical features, anatomical abnormalities, hormonal levels, and gonads found in a dog with male pseudohermaphroditism treated with gonadectomy, clitoridectomy, and urethrostomy.

\section{CASE}

An initially considered mixed-breed intact bitch with 7-month-old was referred because of an exposed vulvar malformation. This structure was not obstructing the vaginal canal but increased progressively in size and protruded from the vulva. Inflammation and dryness of this structure were causing constant lick of the vulva. Clinical parameters were within normal ranges, but the patient exhibited pain when manipulating the vulvar structure. Although there was a fibrous firm tissue in the clitoris area, the vulva was anatomically located. This clitoral structure resembled a "small penis", composed of both bulbourethral glands, a urethra (as confirmed by urethral catheterization), and a firm structure later proved to be bone tissue (os clitoris).

Complete blood count and serum biochemistry did not find abnormalities. The hormonal levels of progesterone $(0.461 \mathrm{ng} / \mathrm{mL})$, estradiol $(23.3 \mathrm{pg} / \mathrm{mL})$, and testosterone $(<10 \mathrm{ng} / \mathrm{mL})$ were consistent with a neutered male/female or a female in anestrus. A radiograph of the perineal area was performed showing the presence of an ossified tissue consistent with a penis (Figure 1A). Abdominal ultrasound revealed a prostate and two rounded, irregular, and hypoechoic structures located bilaterally, cranial, and ventral to the urinary bladder. These structures measured $1.71 \times 0.67 \mathrm{~cm}$ and $1.39 \times 0.75 \mathrm{~cm}$ and were compatible with cryptorchid testicles (Figure 1B). Female gonads and other sexual organs could not be visualized.

The preliminary diagnosis was hermaphroditism, so the animal underwent an exploratory median celiotomy. During abdominal exploration, a tubular blind-end Y-form structure, similar to a uterus, was found in the hypogastric region (Figure 2A and 2B). Adhered to the suspected uterus and in ovarian topography, there were gonads with the appearance of testes but containing a suspensory ligament. All structures were resected (Figure 2C), double ligating the suspensory ligaments, vessels, a supposed to be broad ligament of the uterus, and cervix using 2-0 polyglactin $\left(\text { Vicryl }^{\circledR}\right)^{1}$. The surgical procedure resembled a conventional ovariosalpingohisterectomy. The remaining abdominal viscera were normal, but omental adherence was present, mainly in the urinary bladder

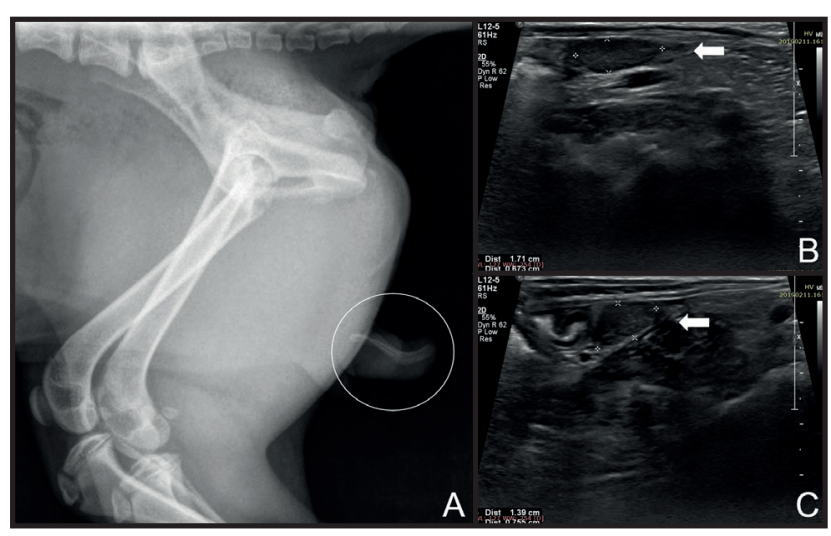

Figure 1. Radiographic and ultrasonographic examination of a canine with male pseudohermaphroditism. A- Lateral radiograph showing the presence of ossified tissue consistent with an os clitoris inside the hypertrophic clitoris (circle). B \& C-Abdominal ultrasound. Two bilateral rounded structures with hypoechoic texture and mild irregular borders (arrows) were located cranial and ventral to the urinary bladder; These structures were supposed to be the testicles. 


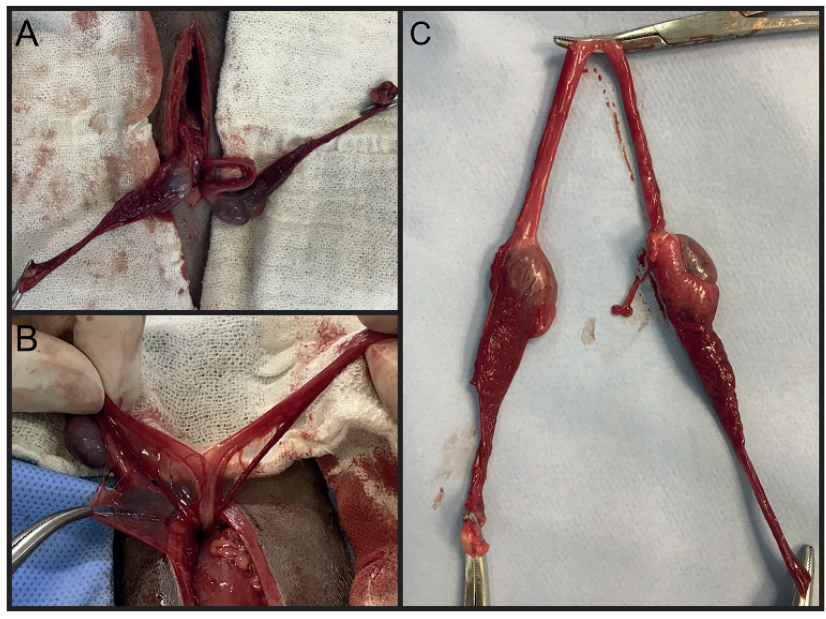

Figure 2. Hypogastric region. Testicles-like structures (A) associated with a tubular blind-end Y-form structure resembling a uterine body and horns (B). The final surgical specimen after resection (C). that was adhered to the remaining broad ligament. The abdominal cavity was closed routinely.

The patient was kept in dorsal recumbency, exposing the perineal and vulvar regions (Figure 3A), and clitoridectomy was performed. An indwelling urethral catheter was placed followed by an episiotomy to improve visualization (Figure 3B). An elliptical incision was performed around the clitoral penis, distal to the bulbourethral glands and the os clitoris (Figure 3C). Blunt dissection was used to detach it from de vulva. The urethra was spatulated and sutured to the mucosa on the ventral region and the skin on the dorsal aspect using 4-0 polydioxanone $\left(\mathrm{PDS}^{\circledR}\right)^{1}$ in simple interrupted fashion (Figure 3D, E \& F). The indwelling catheter was removed by the end of the procedure. The patient

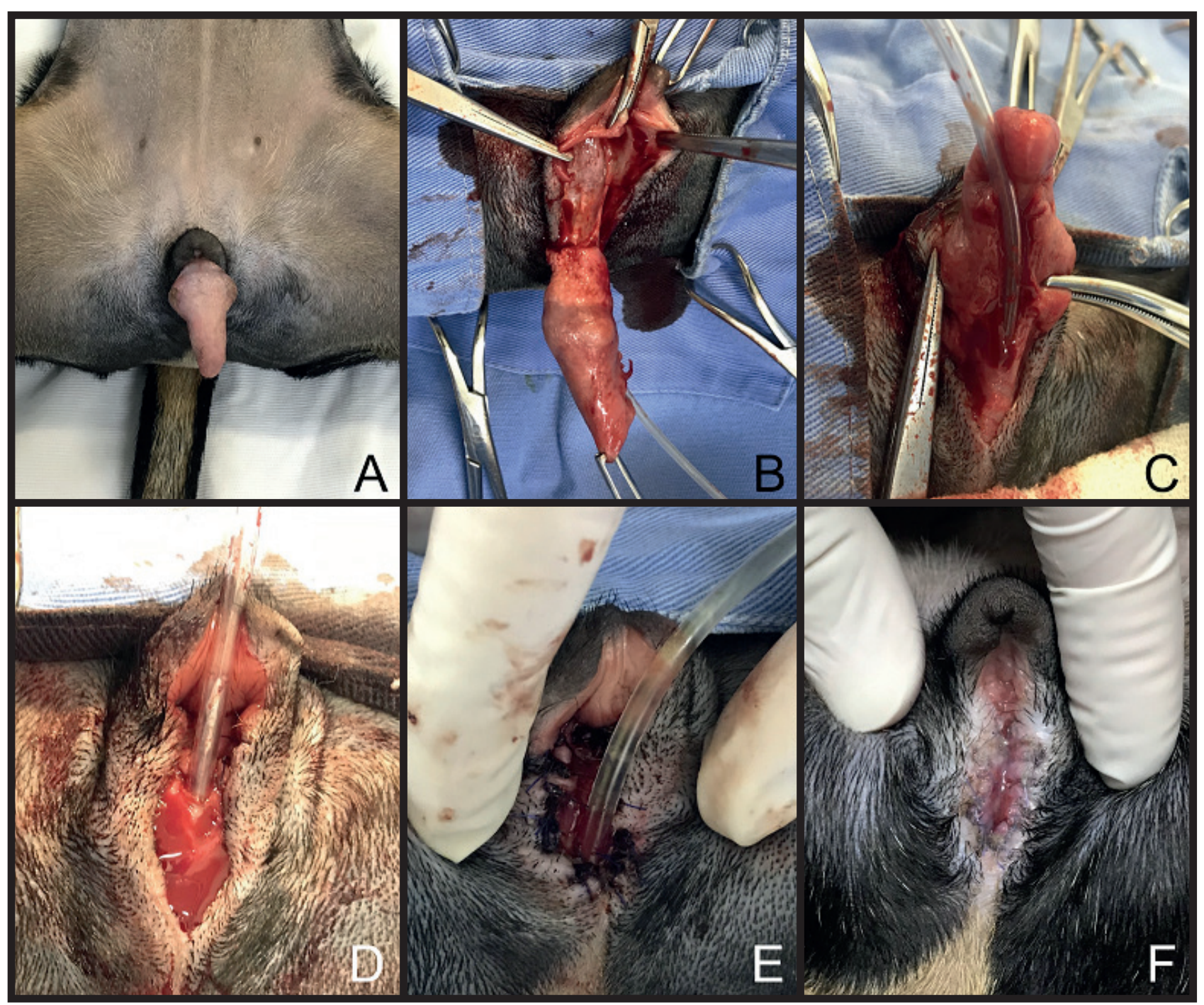

Figure 3. Dorsal recumbency. Exposition of the clitoral region (A) followed by urethral catheterization and an elliptical incision around the clitoris and episiotomy (B), submucous dissection (C), the urethral incision (D), suture of the urethra with the ventral mucosa and dorsal skin (E). Twelve days after surgery showing complete healing $(\mathrm{F})$. 
recovered uneventfully and rested comfortably until discharge from the hospital on the same day.

Cephalexin $\left(\mathrm{Cefex}^{\circledR}\right)^{2}[25 \mathrm{mg} / \mathrm{kg}]$ and ranitidine $\left(\text { Label }^{\circledR}\right)^{3}[2 \mathrm{mg} / \mathrm{kg}$ ] were administered twice a day for 5 days postoperatively. Daily care of the wound and use of Elizabethan collar was advocated. The patient recovered well at home and on the 12th day after surgery sutures were removed and there was no impairment for urination.

Structures removed were histologically evaluated. The triangular structure in the vulva region was composed of an external lining of non-keratinized stratified epithelium with a submucous adjacent to the cavernous body and a central osseous tissue (Figure 4). This structure was histologically compatible with a penile tissue. On the mucous layer, there was extensive focal ulceration along with a high presence of neutrophils, fibrin, and cellular debris; mild lymphoplasmacytic infiltrates were diffusely distributed on the dermal-epidermal junction.

The histological examination of the gonads confirmed that those in the ovary topography were actually testicles. These testicles were composed of regular seminiferous tubules, a single layer of Sertoli cells, without the presence of spermatogenic or sperm cells, and epididymis (Figure 5). Parallel to the uterine horn and in the broad ligament region, there was a circular structure consisting of a muscular layer and pseudostratified epithelium forming a lumen compatible with the vas deferens (Figure 6). After 10 months of follow-up, the patient is alive, without urination impairment or any other clinical signs

\section{DISCUSSION}

The hermaphroditism can be a genetically heterogeneous disturbance, with a different mutation in every canine breed. Most reported cases in current literature refers to purebred dogs, while few authors report the abnormality in mixed-breed dogs [13].

The absence of estrus could be evidence of hermaphroditism. However, estrus was not expected in this dog considering that small to medium-size bitches usually begin estrus within 6 to 13-month-old [20] and the patient was merely 7 -month-old. The animal presented the externalization of the penile structure as the sole clinical sign. The reproductive system had a female origin, being possible that its masculinization occurred due to high testosterone concentration that induces the development of Wolff ducts, resulting in

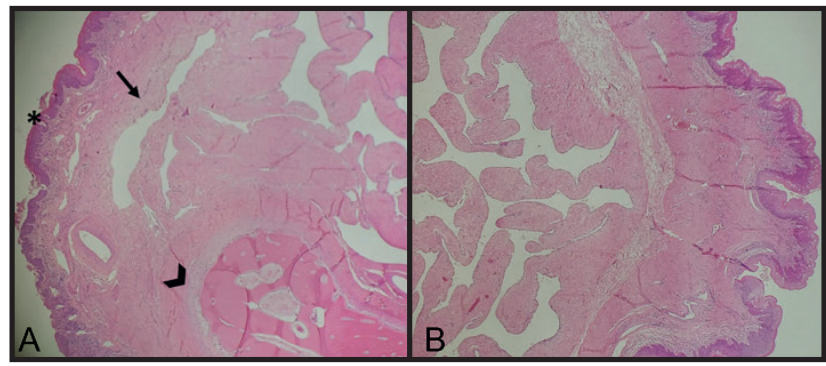

Figure 4. Non-keratinized external stratified lining epithelium (*). A- The submucous adjacent to the cavernous body (arrow) and centrally the osseous tissue (arrowhead) [HE; 10x]. B- Same tissue without the osseous tissue [HE; 20x].

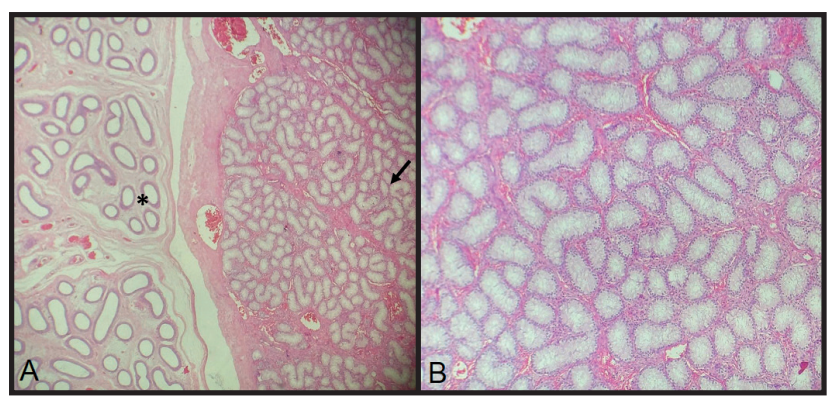

Figure 5. A- Testicles in ovarian topography Epididymis $(*)$ and testicles (arrow) $[\mathrm{HE} ; 10 \mathrm{x}]$. B- Seminiferous tubules with marked diffuse atrophy [HE; 40x].

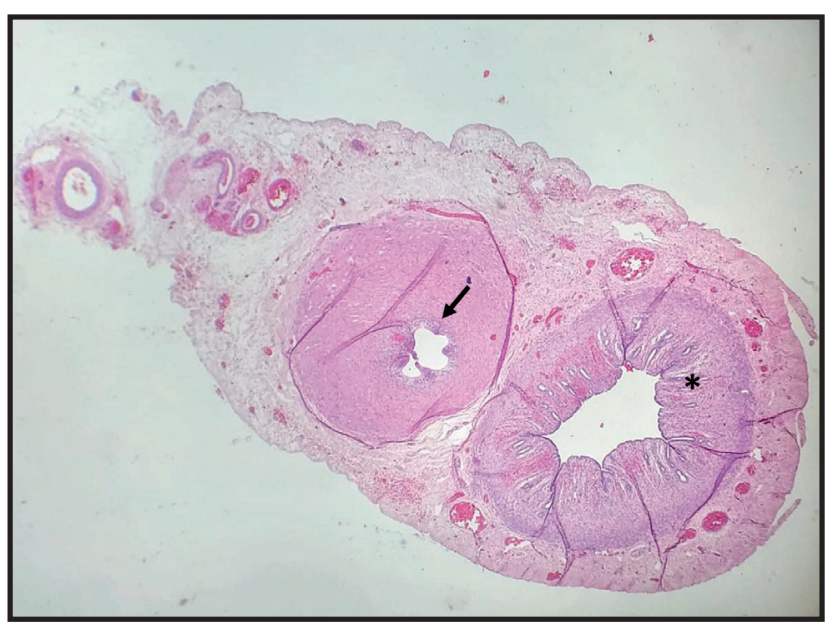

Figure 6. Uterine horn (*) and vas deferens (arrow) [HE; 10x].

the formation of the epididymis, deferent ducts, and seminal vesicles [4]. In these cases, it could lead to an enlarged clitoris [16]. Testosterone also has an important role in dominant and aggressive sexual behavior. The reported blood testosterone concentration ranges between 1 and $5 \mathrm{ng} / \mathrm{mL}$ in normal dogs. Cryptorchid dogs usually have values ranging from 0.1 to $2 \mathrm{ng} / \mathrm{mL}$ [10], the hormonal concentration of the patient was compatible with a neutered male/female or a female in anestrus [6]. 
In this case, the progesterone plasmatic concentration was $0.461 \mathrm{ng} / \mathrm{mL}$. The normal basal concentration before the LH ovulatory peak is $0.1 \mathrm{ng} / \mathrm{mL}$. This value triples on the first day after ovulation, raising about $1 \mathrm{ng} / \mathrm{mL}$ during the estrus and remaining in $2.2 \mathrm{ng} / \mathrm{mL}$ during the diestrus [1]. At the end of the estrus and during all diestrus, the estrogen had a concentration of $10-30 \mathrm{pg} / \mathrm{mL}$, with fluctuations in anestrus (5-30 ng/mL) [3]. This patient had an estradiol concentration of $23.3 \mathrm{pg} / \mathrm{mL}$.

The cytogenetic exam was not available, and so the genetic sex could not be compared with the phenotypic sex. Male pseudohermaphrodites gonadal tissues usually have a testicular origin and XY chromosomal constitution [7]. Female sexual organs could not be individualized in ultrasound examination; although, it was not possible to put away its existence before surgery since ultrasound detection varies according to the estrous cycle. Radiographic examination revealed an osseous tissue in the clitoris region, which is frequent in other reports $[18,19]$. Computed tomography can also be used to evaluate this condition [2].

The exploratory celiotomy allows the examination of the internal genitalia and degree of regression or development of male and female reproductive organs. Also, gonadohysterectomy was necessary to prevent the recurrence of clitoral hypertrophy, reduce the risk of cancer or pyometra formation, prevent the reproduction of animals with hereditary abnormalities, and improve quality of life $[2,10]$.

The sensibility of the clitoris increases as it becomes hypertrophied, resulting in chronic inflammation, constant licking of the mucous, or mucopurulent discharge. Surgery is indicated if there are clinical signs or when the clitoris had an os clitoris or urethra due to an intersex abnormality [19], all situation occurred on the case reported. Identification of the urethral papilla followed by catheterization is essential before surgical resection of the clitoris to prevent inadvertent trauma to the urethra [10]. The surgical procedure described for this patient was designed to preserve the urethra while removing the hypertrophic clitoris. An additional episiotomy aided to expose the base of the clitoris and urethra. The clitoridectomy is reported to be a simple procedure that creates a normal female anatomy and treats the clinical signs associated with the exposed clitoris $[2,6,18]$. Stenosis, bleeding, dehiscence, urinary tract infection, urinary incontinence, and perivulvar dermatitis are possible complications of the clitoridectomy and urethrostomy, but none of these occurred in this case. Constant monitoring of urinary tract infection is recommended [11].

The clitoral penis had histological appearance compatible with the male genital organ, while the abdominal structure was compatible with uterus, testicles, and epididymis. Parallel to the uterine horn and broad ligament there was a histologically confirmed ductus deferens. It is possible to conclude that the patient had only male gonads, which, along with the presence of uterus and a diminished penis, characterized the male pseudohermaphroditism. Dogs with male pseudohermaphroditism are expected to have an external male genital with an os clitoris, uni, or bilateral cryptorchidism, and two completely formed uterine horns [16].

In conclusion, the proposed surgical resection of the external male genitalia associated with exploratory celiotomy and excision of the internal reproductive tract is treated, while preserving the urethra of a dog with male pseudohermaphroditism.

\section{MANUFACTURERS}

1'Johnson \& Johnson do Brasil Indústria e Comércio de Produtos para Saúde Ltda. São Paulo, SP, Brazil.

${ }^{2}$ Cepav Centro de Patologia Clínica Veterinária Ltda. São Paulo, SP, Brazil.

${ }^{3}$ Aché Laboratórios Farmacêuticos S.A. Guarulhos, SP, Brazil.

Declaration of interest. The authors report no conflicts of interest. The authors alone are responsible for the content and writing of the paper.

\section{REFERENCES}

1 Alves I., Mateus M. \& Costa L.L. 2002. Monitorização do ciclo éstrico da cadela para inseminação artificial ou cruzamento. In: Proceedings of the Congresso de Ciências Veterinárias. (Lisboa, Portugal). pp.177-182.

2 Amarpal D.N., Sivanarayanan T.B., Aithal H.P., Kinjavdekar P. \& Pawde A.M. 2013. Clitorectomy for the management of os clitoris in a dog. Indian Journal Canine Practice. 5(2): 139-140.

3 Benetti A.H., Toniollo G.H. \& Oliveira J.A. 2004. Concentrações séricas de progesterona, 17 b-estradiol e cortisol durante o final do próestro, estro e diestro gestacional em cadelas. Ciência Rural. 34(2): 471-478. 
4 Buijtels J.J.C.W.M., De Gier J., Van Haeften T., Kooistra H.S., Spee B., Veldhuis Kroeze E. \& Okkens A.C. 2009. Minimal External Masculinization in a SRY-negative XX Male Podenco Dog. Reproduction in Domestic Animals. 44(5): 751-756.

5 Corcini C.D., Leon P.M.M., Rambo G., Santos E.C.D.S., Varela Junior A.S., Moreira F. \& Lucia Junior T. 2009. Um caso de pseudo-hermafrodita masculino em um suíno. Acta Veterinaria Brasilica. 3(3): 163-165.

6 Costa P.P.C., Braga Filho C.T., Freitas L.A., Santos M.H., Cabral L.A.R., Morais Silveira J.A. \& Araújo A.A. 2017. Hermafroditismo verdadeiro na espécie canina. Acta Scientiae Veterinariae. 45: 1-5.

7 Del Amo A.N., Luca J.D., Zufriategui L., Armocida A., Barbeito C.G. \& Gobello C. 2001. Male pseudohermaphroditism in a dog: a case report. Communications in Theriogenology. 1: 1-11.

8 Delfini A., Toniollo G.H., Canola J.C., Alessi A.C., Lui J.F., Martins Filho L.P. \& Rodrigues V. 2007. Pseudohermafroditismo masculino em cão da raça American Pit-Bull Terrier. Ciência Animal Brasileira. 8(2): 333-338.

9 Fantoni M.S., Silva B.C., Ferreira L.F.L., Valle G.R. \& Rachid M.A. 2012. Male pseudohermaphroditism in bitch. Arquivo Brasileiro de Medicina Veterinária e Zootecnia. 64(3): 763-765.

10 Feldman E.C. \& Nelson R.W. 2004. Vaginal defects, vaginitis, and vaginal infection. In: Feldman E.C. \& Nelson R.W. (Eds). Canine and Feline Endocrinology and Reproduction. 3rd edn. Philadelphia: W.B. Saunders, pp.901-918.

11 Fossum T.W. 2008. Cirurgia da Bexiga e Uretra. In: Fossum T.W. (Ed). Cirurgia de Pequenos Animais. 3.ed. Rio de Janeiro: Elsevier, pp.663-701.

12 Lopes M.D. \& Volpato R. 2015. Principais Doenças do Trato Reprodutivo de Cães. In: Jericó M.M., Kogika M.M. \& Andrade Neto J.P. (Eds). Tratado de Medicina Interna de Cães e Gatos. Rio de Janeiro: Roca, pp.4765-4807.

13 Max A., Grabiec A., Sacharczuk M., Sysa P., Jurka P. \& Krzyzewska A. 2012. 78, XX testicular DSD syndrome in a mongrel dog. Reproduction in Domestic Animal. 47(1): e7-e11. doi: 10.1111/j.1439-0531.2011.01834.x.

14 Meyers-Wallen V.N. 2000. CVT Update: Inherited Disorders of the Reproductive Tract in Dogs and Cats. In: Kirk R.W. \& Bonagura J.D. (Eds). Current Veterinary Therapy. 13th edn. Philadelphia: W.B. Saunders, pp.904-908.

15 Paz G.M., Coelho N.D.G.D., Torres R.C.S., Alves F.S., Vieira R., Okano B.S. \& Veado J.C.C. 2017. Piometra associada a criptorquidismo em cão pseudo-hermafrodita masculino com síndrome da persistência dos ductos de Müller. Revista Brasileira de Reprodução Animal. 41(4): 727-731.

16 Ponglowhapan S., Glaewketgarn N. \& Lohachit C. 2011. Hermaphroditism with Bilateral Ovotestes in a Dog: A Case Report. The Thai Journal of Veterinary Medicine. 41: 180.

17 Schlafer D.H. \& Miller R.B. 2007. Pathology of the genital system of the nongravid female. In: Jubb K.V.F., Kennedy P.C. \& Palmer N. (Eds). Pathology of Domestic Animals. 5th edn. Edinburgh: Saunders Elsevier, pp.431-444.

18 Silversides D.W., Benoit J.M., Collard F. \& Gilson C. 2011. Disorder of sex development (XX male, SRY negative) in a French bulldog. Canadian Veterinary Journal. 52(6): 670.

19 Smeak D.D. \& Turner H. 2014. Treatment of clitoral hypertrophy containing an os clitoris and urethra in a young greyhound dog: A detailed surgical description. Canadian Veterinary Journal. 55(9): 836-840.

20 Souza R.H.F.A. 2015. Avaliação sérica de estrógeno e progesterona por método de imunoensaio multianalito em cadelas durante o ciclo estral. 57f. São Paulo, SP. Tese (Mestrado em Reprodução Animal) - Programa de Pós-Graduação da Faculdade de Medicina Veterinária e Zootecnia, Universidade de São Paulo. 